\title{
Characterization of a novel ranavirus isolated from grouper Epinephelus tauvina
}

\author{
Q. W. Qin ${ }^{1,2, *}$, S. F. Chang ${ }^{3}$, G. H. Ngoh-Lim ${ }^{3}$, S. Gibson-Kueh ${ }^{3}$, C. Shi ${ }^{1}$, T. J. Lam ${ }^{1,2}$ \\ ${ }^{1}$ Tropical Marine Science Institute and ${ }^{2}$ Department of Biological Sciences, The National University of Singapore, \\ 10 Kent Ridge Crescent, Singapore 119260 \\ ${ }^{3}$ Central Veterinary Laboratory, Agri-food and Veterinary Authority, 60 Sengkang East Way, Singapore 548596
}

\begin{abstract}
A large icosahedral virus was isolated from diseased grouper Epinephelus tauvina. The virus grew well in several cultured fish cell lines, with stable and high infectivity after serial passages in grouper cell line (GP). The virus was sensitive to both acid and heat treatments. Virus replication was inhibited by 5-iodo-2-deoxyuridine (IUDR), indicative of a DNA-containing genome. The virus infectivity was reduced with ether treatment, suggesting that the virus was lipid-enveloped. Electron micrographs showed abundant cytoplasmic icosahedral virons in the virus-infected GP cells. The size of the intracellular nucleocapsid was $154 \mathrm{~nm}$ between the opposite sides, or $176 \mathrm{~nm}$ between the opposite vertices with an inner electron-dense core of $93 \mathrm{~nm}$. Virus particles were released through budding from plasma membranes with a size of $200 \mathrm{~nm}$ in diameter. SDS-PAGE of purified virus revealed 20 structural protein bands and a major capsid protein (MCP) of $49 \mathrm{kDa}$. A DNA fragment of $\sim 500$ nucleotides was successfully amplified by polymerase chain reaction (PCR) using the primers from conserved regions of the MCP gene of frog virus 3 (FV3), the type species of Ranavirus. Subsequent multiple alignment and phylogenetic analysis showed that the newly isolated grouper virus was closely related to largemouth bass virus (LMBV), FV3 and Regina ranavirus (RRV). Our data suggests that the virus isolate is a novel member of genus Ranavirus, family Iridoviridae. We tentatively name the virus as Singapore grouper iridovirus (SGIV). SGIV was able to cause serious systemic disease capable of killing $96 \%$ of grouper fry.
\end{abstract}

KEY WORDS: Fish virus · Iridovirus · Ranavirus · Iridoviridae · Grouper · Epinephelus tauvina Resale or republication not permitted without written consent of the publisher

\section{INTRODUCTION}

Iridoviruses are well known as causative agents of serious systemic diseases among feral, cultured food and ornamental fish, and have been identified from at least 19 fish species in the last decade (Piaskoski \& Plumb 1999, Hyatt et al. 2000). Outbreaks of iridoviral diseases have been reported in Australia (Langdon et al. 1986), France (Pozet et al. 1992), Germany (Ahne et al. 1989), Denmark (Bloch \& Larsen 1993), Finland (Tapiovaara et al. 1998), South Carolina, USA (Plumb et al. 1996), Japan (Inouye et al. 1992) and SE Asia (Chua et al. 1994, Kasornchandra \& Khongpradit 1995, Chou et al. 1998). The mortality of fish due to those iridovirus infections ranged from 30\% (adult fish) to $100 \%$ (fry). Histopathological signs in iridovirus-infected fish may include enlargement of cells and necrosis of the renal and splenic hematopoietic tissues. Iridoviruses are large double-stranded DNA viruses, icosahedral, 120 to 300 $\mathrm{nm}$ in diameter and contain a spherical deoxyribonucleo-protein core surrounded by a lipid membrane containing protein subunits. Fish iridoviruses can be isolated by using several cell lines represented by bluegill fry-2 (BF-2) (Wolf \& Quimby 1966).

Grouper, Epinephelus sp., the major species being maricultured in Singapore and other SE Asian countries, are high-priced and popular seafood fish. Nevertheless, with rapidly developing farming activities in SE Asia, the opportunity for infectious diseases has greatly increased in highly valued fishes such as grouper. Outbreaks of a novel viral disease called 'Sleepy Grouper Disease' (SGD) have been first reported in brown-spotted grouper E. tauvina in Singapore in 1994 (Chua et al. 1994). SGD resulted in 
significant economic losses in some Singapore marine net-cage farms. The pathogen was suggested as an iridovirus based on histopathological and morphological evidence. However, the virus was not isolated by cell culture, and no biochemical data are available to confirm the virus as a member of the family Iridoviridae (Chua et al. 1994). In 1998, an outbreak of the same disease occurred in fry and adult brown-spotted groupers. The grouper fry were imported from other SE Asian countries and cultured in fish farms in Singapore. The outbreak lasted several weeks and resulted in more than $90 \%$ mortality. The present work describes isolation of the viral pathogen in cell culture, investigation of virus infectivity and pathogenicity, and characterization of the virus based on biochemical, structural and molecular properties.

\section{MATERIALS AND METHODS}

Cell lines and maintenance. Three local tropical marine-fish cell lines and 3 commercial fish cell lines were used. Grouper (GP) embryo cells from brownspotted grouper Epinephelus tauvina (Chew-Lim et al. 1994), Asian seabass fry (SF) cells from Lates calcarifer (Chang et al. 2001), and Asian seabass (SB) embryo cells (Chong et al. 1987) were cultured in Eagles' minimum essential medium (EMEM) containing 10\% foetal bovine serum (FBS), $0.116 \mathrm{M}$ sodium chloride, $100 \mathrm{IU} \mathrm{m}^{-1}$ of penicillin and $100 \mathrm{\mu g} \mathrm{ml}^{-1}$ of streptomycin. The $\mathrm{pH}$ of the medium was adjusted to $7.2-7.4$ with $7 \%$ sodium bicarbonate and buffered with $5 \mathrm{mM}$ HEPES. Bluegill fry (BF2) cells (Wolf \& Quimby 1966), fathead minnow (FHM) cells (Gravel \& Malsberger 1965) and epithelioma papillosum of carp (EPC) cells from Cyprinus carpio (Fijan et al. 1983) were cultured in EMEM containing $10 \% \mathrm{FBS}, 100 \mathrm{IU} \mathrm{ml}^{-1}$ penicillin and $100 \mathrm{\mu g} \mathrm{ml}^{-1}$ streptomycin and $16 \mathrm{mM}$ Tris- $\mathrm{HCl}(\mathrm{pH}$ 7.5). All cell cultures were cultured and maintained at $25^{\circ} \mathrm{C}$.

Virus isolation. Virus sample A3/12/98 was originally isolated from a pool of infected groupers. Pooled samples of spleen, kidney, liver and heart from the diseased fish were dissected and homogenized in approximately 10 volumes of MEM with antibiotics in the absence of FBS. The tissue homogenates were centrifuged at $2000 \times g$ for $10 \mathrm{~min}$ at $4^{\circ} \mathrm{C}$, and the supernatants were passed through a sterile $0.45 \mu \mathrm{m}$ filter (Millipore). The filtrates were inoculated onto confluent monolayers of GP cells prepared $24 \mathrm{~h}$ previously. When advanced cytopathic effect (CPE) was observed, the cell culture supernatants were harvested as virus source and stored at $-80^{\circ} \mathrm{C}$ until used.

Infection and replication of grouper virus in fish cell cultures. Cell lines (GP, SF, SB, BF-2, FHM and EPC) were tested for their susceptibility to virus isolate
A3/12/98. All cells were cultured in $25 \mathrm{~cm}^{2}$ tissue culture flasks (NUNC ${ }^{\mathrm{TM}}$ Brand Products) and infected $24 \mathrm{~h}$ after subculture. A3/12/98 virus infected cell culture supernatant was adsorbed onto cell monolayers at a multiplicity of infection (MOI) of approximately 0.1 for $1 \mathrm{~h}$. The inoculum was removed and the monolayers incubated in fresh culture medium supplemented with $5 \%$ FBS for $3 \mathrm{~d}$ and examined for CPE daily. After $3 \mathrm{~d}$, all cell culture supernatants were harvested and titrated onto GP cells. For virus titration, $0.1 \mathrm{ml}$ of 10 -fold serial dilutions of virus were inoculated into 4 wells of subconfluent cells on 24 -well plates (NUNC ${ }^{\mathrm{TM}}$ Brand Products). The plates were incubated for $7 \mathrm{~d}$ at $25^{\circ} \mathrm{C}$, and $\mathrm{CPE}$ was checked daily. The virus titers were expressed as the $50 \%$ tissue culture infective dose $\left(\mathrm{TCID}_{50}\right)$ according to the method of Reed \& Muench (1938).

Physio-chemical properties of the virus. Stability of serial passages: The virus isolate was propagated and re-passaged 8 additional times in GP cell cultures at a MOI of approximately 0.1. For the first passage, cell cultures were inoculated with virus isolated from the diseased grouper. The following passages were prepared using virus propagated from the former passage. The viral infectivity of each passage was measured by the $\mathrm{TCID}_{50}$ assay.

Temperature sensitivity: Samples from the 4th virus passage were used for a temperature sensitivity test. The virus was heated at $56^{\circ} \mathrm{C}$ for $30 \mathrm{~min}$, and the residual virus titers determined in GP cell culture.

pH sensitivity: The $\mathrm{pH}$ sensitivity of the virus was determined by treating the virus with low $\mathrm{pH}$ (3.0) in MEM with $0.1 \mathrm{M}$ citrate buffer. After $4 \mathrm{~h}$ treatment at $4^{\circ} \mathrm{C}$, the virus was titered in GP cells.

Organic solvent sensitivity: The virus was treated with $75 \%$ of ether for $2 \mathrm{~h}$ at room temperature. The sample was continuously mixed to prevent the organic and aqueous phase from separating. The ether was removed completely by evaporation at room temperature, and the virus solution was titered in GP cells.

Sensitivity to IUDR: The nucleic acid type of the virus was determined by growing the virus in growth medium containing $10^{-5} \mathrm{M}$ 5-iodo-2-deoxyuridine (IUDR; Sigma). Virus titers were compared with that of virus propagated in normal growth medium in the absence of IUDR.

Virus purification: The virus was purified as described by Steiner et al. (1991) with minor modifications. Briefly, confluent monolayers of GP cells were inoculated with the virus at a MOI of 0.1. When CPE was prominent after $3 \mathrm{~d}, 100 \mathrm{ml}$ of remaining cells and culture fluid were harvested and centrifuged at $12000 \times g$ for $30 \mathrm{~min}$ at $4^{\circ} \mathrm{C}$. The supernatant (SN1) was collected and stored at $4^{\circ} \mathrm{C}$ while the pellet was resuspended with $2 \mathrm{ml} \mathrm{SN1}$, followed by 3 cycles of rapid freezing/thawing and ultrasonication. The virus-cell 
debris resuspension was then centrifuged at $4000 \times g$ for $20 \mathrm{~min}$ at $4^{\circ} \mathrm{C}$. The supernatant (SN2) was collected, pooled with SN1 and stored overnight at $4{ }^{\circ} \mathrm{C}$. Virus particles were pelleted from the pooled SN1 and SN2 by centrifugation at $10000 \times g$ for $8 \mathrm{~h}$ at $4^{\circ} \mathrm{C}$ and resuspended in $2 \mathrm{ml} \mathrm{TN}$ buffer (50 mM Tris- $\mathrm{HCl}, 150 \mathrm{mM}$ $\mathrm{NaCl}_{1} \mathrm{pH}$ 7.5). The suspension was loaded onto 15 to $60 \%(\mathrm{w} / \mathrm{v})$ sucrose gradients and centrifuged at $150000 \times g$ (Beckman, SW 41 Ti rotor) for $1 \mathrm{~h}$ at $4^{\circ} \mathrm{C}$. Resulting virus bands were collected by puncturing the centrifuge tubes with a needle. Virus was diluted with TN buffer, repelleted at $100000 \times g$ for $1 \mathrm{~h}$, and stored at $-20^{\circ} \mathrm{C}$ after resuspension in $200 \mu \mathrm{lN}$ buffer.

Electron microscopy (EM). Negative staining of virus: A drop of gradient purified virus solution was applied onto a carbon coated formvar filmed copper grid. The grid was dried by blotting its edge with a filter paper and then the grid was negatively stained with $2 \%$ phosphotungstic acid (PTA, pH 6.8) for $30 \mathrm{~s}$.

UItrathin sections for EM: Confluent GP cells grown on $75 \mathrm{~cm}^{2}$ culture flasks (NUNC ${ }^{\mathrm{TM}}$ Brand Products) were infected with the virus at 0.1 MOI. After the appearance of advanced CPE, infected cells were harvested and pelleted by centrifugation. The cell pellets were first fixed with $2.5 \%$ glutaraldehyde (SPI, EM grade) in $0.1 \mathrm{M}$ cacodylate buffer, $\mathrm{pH} 7.2$ for 2 to $3 \mathrm{~h}$, the cells were then washed with cacodylate buffer, and post-fixed in $1 \%$ osmium tetroxide for $1 \mathrm{~h}$. The cell pellet was carefully mixed with $2 \%$ melted agrose at $45^{\circ} \mathrm{C}$ and immediately cooled on ice. Cubes $\left(1 \mathrm{~mm}^{3}\right)$ of the agrose-cell mixture were then dehydrated in a graded series of ethanol and embedded in resin (EMS, SPUR'S Kit). Ultrathin sections were cut with an ultramicrotome (Reichert-Jung), and then double-stained with saturated aqueous uranyl acetate and lead citrate. Both negative-stained and ultrathin-sectioned specimens were examined with a transmission electron microscope (JEOL JEM-1000CX II) at $100 \mathrm{kV}$.

Sodium dodecyl sulfate polyacrylamide gel electrophoresis (SDS-PAGE) of viral proteins. Virus structural proteins were separated by SDS-PAGE using the discontinuous system described by Laemmli (1970) with a $12 \%$ resolving gel and a $3 \%$ stacking gel. Purified virus was treated at $100^{\circ} \mathrm{C}$ for $3 \mathrm{~min}$ in sample buffer containing 1\% SDS and 2\% 2-mercaptoethanol, and applied onto the gel. Electrophoresis was run at a constant voltage of $200 \mathrm{~V}$ for $1 \mathrm{~h}$. After electrophoresis, the gel was fixed and stained with $0.2 \%$ of Coomassie Brilliant Blue.

Polymerase chain reaction (PCR) analysis of the viral major capsid protein (MCP) gene. Isolation of DNA: Total cellular DNA was extracted from the grouper virus-infected GP cells and used as a DNA template for PCR. The DNA from mock-infected GP cells was used as negative control. Frog virus 3 (FV3) was obtained from the Virology Laboratory of Agrifood Authority of Singapore. The DNA, extracted from FV3-infected BF-2 cells, served as a positive control. Briefly, the cells were incubated with DNA extraction buffer (100 mM Tris-HCl, pH 8.0, 50 mM EDTA, 200 $\mathrm{mM} \mathrm{NaCl}$ and $1 \% \mathrm{SDS}$ ) containing $100 \mathrm{\mu g} \mathrm{ml}^{-1}$ of Proteinase $\mathrm{K}$ at $50^{\circ} \mathrm{C}$ for $18 \mathrm{~h}$. After cooling to room temperature, the mixture was extracted twice with an equal volume of phenol-chloroform. The DNA was precipitated with ethanol and dissolved in TE buffer (10 mM Tris-HCl, pH 7.5, 1 mM EDTA).

PCR amplification and sequence analysis of viral DNA: Primers for amplification of the partial MCP gene were synthesised according to 2 conserved partial sequences of the gene encoding frog virus $3 \mathrm{MCP}$ (Mao et al. 1997). The sequences of individual primers are (5' to $3^{\prime}$ ) MCP forward primer: GACTTGGCCACTTATGAC and MCP reverse primer: GTCTCTGGAGAAGAAGAA. Prior to amplification, PCR reactions were incubated at $94^{\circ} \mathrm{C}$ for $2 \mathrm{~min}$. Amplification conditions were as follows: 35 cycles of denaturation at $94^{\circ} \mathrm{C}$ for $1 \mathrm{~min}$, annealing at $45^{\circ} \mathrm{C}$ for $2 \mathrm{~min}$ and extension at $72^{\circ} \mathrm{C}$ for $1 \mathrm{~min}$, followed by an extension reaction at $72^{\circ} \mathrm{C}$ for $10 \mathrm{~min}$. The PCR products were electrophoresed on $1.2 \%$ agarose gels and visualized by ethidium bromide staining. In order to confirm that the DNA amplified from the virus was the authentic product of the MCP gene, PCR products ( 500 bp) were purified using QIAquick Gel Extraction kit (QIAGEN), and cloned into the pGEM-T Easy vector (Promega) using the TA cloning method. Both DNA strands were sequenced using an Applied Biosystems PRISM 377 automated DNA sequencer by the dye termination method. The ABI PRISM BigDye Terminator Cycle Sequencing Ready Reaction Kit (Applied Biosystems) was used. In order to determine relationship of the newly isolated virus with representative iridoviruses, a multiple alignment of the virus MCP sequence with FV3, largemouth bass virus (LMBV), Regina ranavirus (RRV), fish lymphocystis virus (LCDV), infectious spleen and kidney necrosis virus (ISKNV), chilo iridescent virus (CIV) and tipula iridescent virus (TIV) was performed using the Clustal X program (Thompson et al. 1997) and generated by GenDoc (Nicholas \& Nicholas unpubl. $)^{1}$. Based on the alignment, a phylogenetic tree was constructed using Clustal X and generated by Treeview program (Page 1996). GenBank accession numbers for the sequences used in multiple alignment are as follows: FV3, U36913; LMBV, AF080250; RRV, AF080218; LCDV, L63545; ISKNV, AF371960; CIV, AF303741; TIV, M33542.

\footnotetext{
${ }^{1}$ K. B. Nicholas \& H. B. Nicholas Jr. (1997) GenDoc: a tool for editing and annotating multiple sequence alignment. Distributed by the authors (www.psc.edu/biomed/genedoc).
} 
Pathogenicity tests. Experimental infection of fish was performed by intraperitoneal injection (i.p.). Healthy brown-spotted groupers (10 g average weight) were obtained from a local fish farm and acclimatised to the aquara for 1 wk before infection. Sixty fish in 4 tanks were injected with $0.1 \mathrm{ml}$ of the 4 th passage virus at a concentration of $10^{5} \mathrm{TCID}_{50} \mathrm{ml}^{-1}$, and 30 fish in 2 tanks were injected with $0.1 \mathrm{ml}$ non-infected cell culture medium as controls. Fish mortality was monitored for $10 \mathrm{~d}$, and the moribund fish were examined by cell culture re-isolation of the virus.

\section{RESULTS}

Virus isolation and infection in fish cell cultures. Grouper virus was isolated from pooled diseased organs. Viral CPE was first observed after $24 \mathrm{~h}$ inocula-
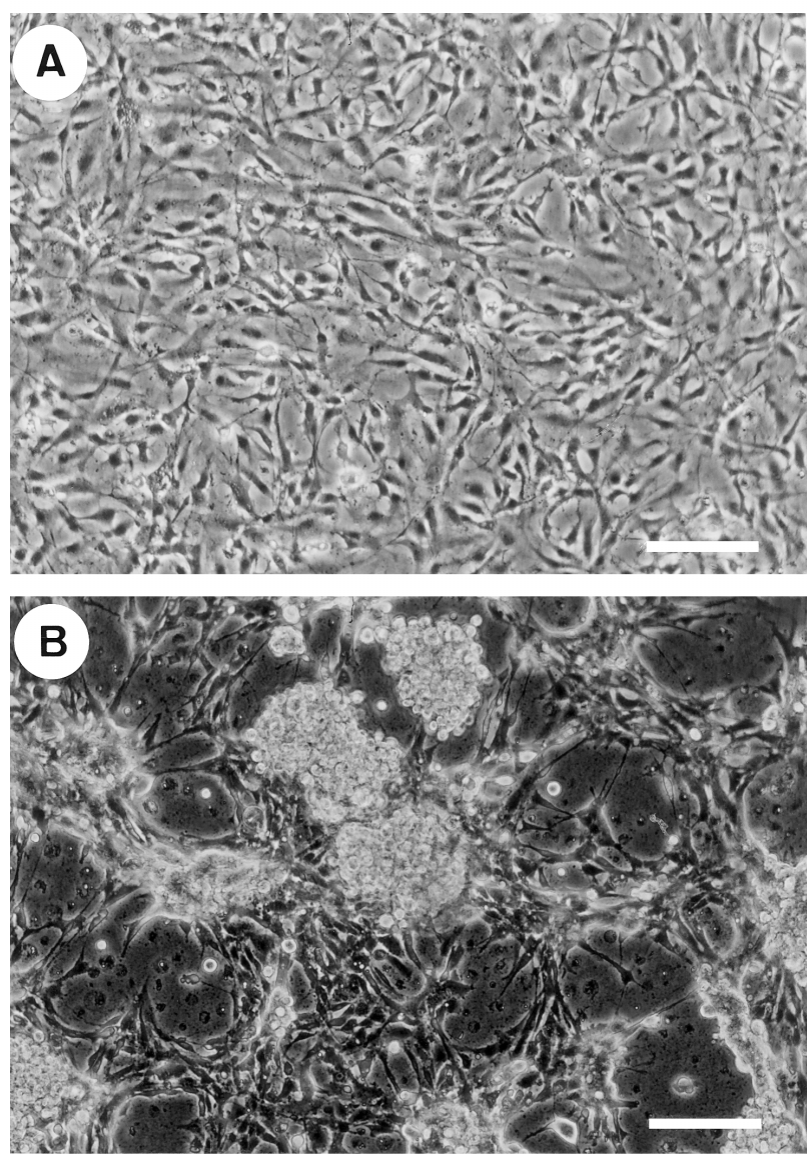

Fig. 1. Epinephelus tauvina. Grouper (GP) cells infected with the grouper iridovirus. (A) Normal monolayer of GP cell cultures. (B) The cytopathic effect (CPE) of the grouper virus in GP cells $24 \mathrm{~h}$ after infection. Numerous small foci were generated at the monolayer cell cultures with lysing cell debris in the foci, rounding cells at the edge of foci and detached round-cell aggregations. Scale bar $=50 \mu \mathrm{m}$ tion at $25^{\circ} \mathrm{C}$. At the initial stage of $\mathrm{CPE}$, numerous small foci appeared in the cell monolayer with cell lysis and round-cell aggregations at the edge of foci (Fig. 1B). As the CPE progressed, additional adjoining cells became rounded and detached until the entire monolayer was eventually affected and lysed within $4 \mathrm{~d}$.

Infection and replication of A3/12/98 virus in different fish cell cultures showed early appearance of CPE within $24 \mathrm{~h}$ in GP, SF and FHM cells (Table 1), whereas $\mathrm{CPE}$ for the same virus developed more slowly in EPC, $\mathrm{SB}$ and BF-2 cells. High titers were detected in GP, SF and FHM cells. The virus yield in GP cell cultures reached a high of $10^{7.0} \mathrm{TCID}_{50} \mathrm{ml}^{-1}$, whereas titres from EPC, BF-2, SB, FHM and SF cultures ranged from $10^{3.0}$ to $10^{5.7} \mathrm{TCID}_{50} \mathrm{ml}^{-1}$.

Stability of serial passages. Virus titres from various serial passages were obtained in GP cells. The virus titres decreased from the first passage high of $10^{7.3} \mathrm{TCID}_{50} \mathrm{ml}^{-1}$ to the second passage of $10^{6.3} \mathrm{TCID}_{50} \mathrm{ml}^{-1}$. The infectivity of virus was stable from the second passage and a high titre of $10^{6.0} \mathrm{TCID}_{50} \mathrm{ml}^{-1}$ was maintained until the ninth passage.

Sensitivity of the grouper virus to physio-chemical treatments. Following physio-chemical treatments including heat, exposure to low $\mathrm{pH}$, organic solvents and a DNA inhibitor, the virus was titered in GP cells. As shown in Table 2, the virus was sensitive to both heat

Table 1. Infection and replication of grouper virus in 6 fish cell lines: grouper embryo (GP), seabass fry (SF), fathead minnow (FHM), seabass (SB), epithelioma papillosum cyprini (EPC), and bluegill fry-2 (BF-2). Virus culture supernatants from

each cell line were titrated in GP cells $7 \mathrm{~d}$ post infection

\begin{tabular}{|lcc|}
\hline Cell line & $\begin{array}{c}\text { Time of } \\
\text { first appearance } \\
\text { of CPE (h) }\end{array}$ & $\begin{array}{c}\text { Virus titer } \\
\text { (TCID }_{50} \mathrm{ml}^{-1} \text { ) }\end{array}$ \\
\hline GP & 24 & $10^{7.0}$ \\
SF & 24 & $10^{5.7}$ \\
FHM & 24 & $10^{5.0}$ \\
SB & 60 & $10^{4.6}$ \\
EPC & 48 & $10^{3.0}$ \\
BF-2 & 72 & $10^{4.0}$ \\
\hline
\end{tabular}

Table 2. Sensitivity of the grouper virus isolate to physical and chemical treatments. The virus was treated with various physio-chemical treatments, and the treated virus titers were measured in GP cells $7 \mathrm{~d}$ post infection

\begin{tabular}{|lc|}
\hline Treatments & Virus titer $\left(\mathrm{TCID}_{50} \mathrm{ml}^{-1}\right)$ \\
\hline Control (non-treat) & $10^{7.0}$ \\
Heat $\left(56^{\circ} \mathrm{C}, 30 \mathrm{~min}\right)$ & $10^{3.7}$ \\
pH 3.0 & $10^{3.0}$ \\
Ether & $10^{3.0}$ \\
IUDR $\left(10^{-5.0} \mathrm{M}\right)$ & $10^{1.7}$ \\
\hline
\end{tabular}



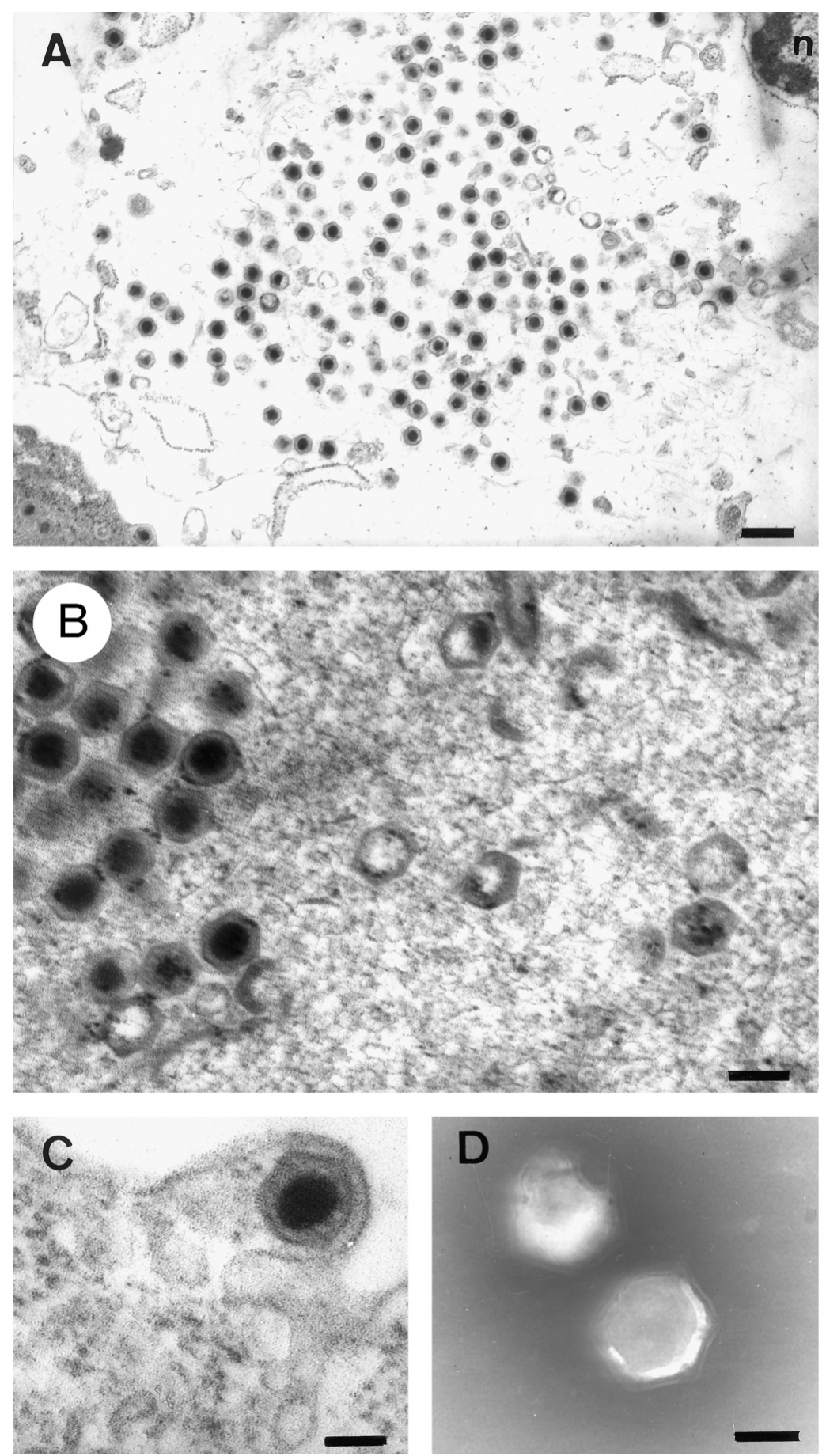

Fig. 2. Transmission electron micrographs of the grouper virus-infected cells. (A) Low magnification micrograph of the ultrathin section of a virus-infected cell. Large amounts of cytoplasmic nucleocapsids were located in geometrical arrays at the assembly sites, or scattered individually. n: nucleus. Scale bar $=500 \mathrm{~nm}$. (B) Viral nucleocapsids in different stages of assembly at cytoplasm, ranging from incomplete particles containing empty or partially formed electron-dense cores to complete mature icosahedral particles containing full electron-dense cores. Scale bar $=150 \mathrm{~nm}$. (C) Virus acquired envelope through budding from the plasma membrane of an infected cell. Scale bar $=100 \mathrm{~nm}$. (D) Negative staining of purified grouper virus revealed the 3-layered virus structure with an inner electron-dense core surrounded by a lighter area. Scale bar $=100 \mathrm{~nm}$ $\left(56^{\circ}, 30 \mathrm{~min}\right)$ and low $\mathrm{pH}(3.0)$. Treatment of the virus with ether reduced the titer from $10^{7.0}$ to $10^{3.0} \mathrm{TCID}_{50} \mathrm{ml}^{-1}$ dramatically, suggesting that the virus is lipid enveloped. The replication of virus was almost completely inhibited in a cell culture medium containing $10^{-5.0} \mathrm{M}$ IUDR, indicating that the virus possessed a DNA genome.

EM of the virus. Examination of ultrathin sections revealed large amounts of intracellular virus particles in the cytoplasm of infected GP cells. Virions were scattered throughout the cytoplasm as individual viruses, or in paracrystalline arrays at assembly sites (Fig. 2A). Nucleocapsids within assembly sites were in different assembly stages, ranging from immature, incomplete particles containing empty, or partially formed cores to complete mature icosahedral particles containing full electron-dense cores (Fig. 2B). No viruses were found inside the nucleus. Virions are icosahedral with a mean diameter of $154 \pm 6 \mathrm{~nm}(\mathrm{n}=15)$ between opposite sides, or $176 \pm 8 \mathrm{~nm}$ $(n=15)$ between the opposite vertices; the mean diameter of the inner electrodense core was $93 \pm 5 \mathrm{~nm}(\mathrm{n}=15)$. Virus particles were enveloped and were released by budding from the cell plasma membranes (Fig. 2C). Negatively stained purified enveloped virus showed a typical hexagonal shape, and the structure of virus was 3-layered with an inner electron-dense core surrounded by a lighter coat (Fig. 2D). The particles were consistently larger than those found in ultrathin sections, with a mean diameter of $200 \pm 13 \mathrm{~nm}(\mathrm{n}=15)$.

SDS-PAGE of viral proteins. More than 20 polypeptides were detected by SDS-PAGE. The putative MCP has a molecular mass of $49 \mathrm{kDa}$ (Fig. 3).

PCR amplification. A specific product with a size of about 500 base pairs (bp) was successfully amplified from DNA extracted from grouper virusinfected GP cells. A 500 bp PCR product was obtained from the template DNA of FV3-infected BF-2 cells as positive control and nothing was amplified from the negative control of mock infected GP cells. 


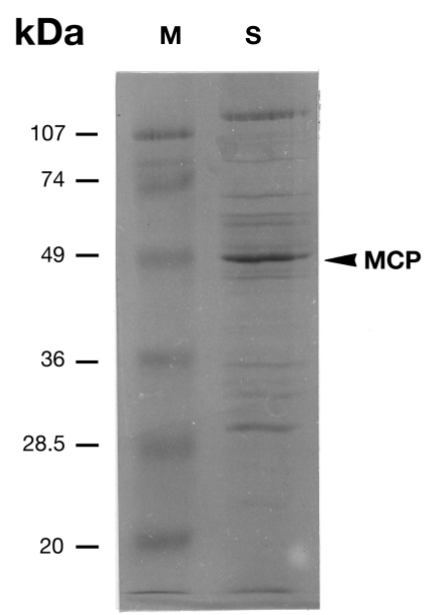

Fig. 3. SDS-PAGE analysis of the viral proteins. It was possible to distinguish more than 20 polypetides; the major capsid protein (MCP) was at the position of $49 \mathrm{kDa}$. The gel was stained with Coomassie Brilliant Blue. M: molecular weight markers; S: virus sample

Sequence analysis of the PCR-amplified grouper virus MCP gene. The PCR fragment was cloned into the pGEM-T Easy vector and sequenced. A $531 \mathrm{bp}$ nucleotide sequence including primers was obtained, and the sequence data have been deposited into GenBank and assigned accession number AF480877. To determine the genetic relationship between grouper virus isolate and other iridoviruses, the obtained nucleotide sequence and deduced amino acid sequence of the grouper virus isolate were aligned with published sequences of the other iridoviruses. At the nucleotide level, the grouper virus isolate was $72 \%$ identical to RRV, $70 \%$ identical to FV3 and LMBV. In contrast, the grouper virus was only $53 \%$ identical to LCDV, whereas 48,48 and $36 \%$ identical to CIV, TIV and ISKNV respectively. The predicted amino acid sequence of the grouper virus was 70,69, $69,47,41,39$ and $34 \%$ identical to the partial MCP sequence obtained from LMBV, RRV, FV3, LCDV, TIV, CIV and ISKNV respectively without counting the primers (Fig. 4). A phylogenetic tree was constructed based on the multiple alignment result shown in Fig. 5. This phylogenetic tree shows that the newly isolated grouper virus most likely represents a novel species of Ranavirus distinct from LMBV, RRV and FV3.

Pathogenicity of the virus. The virus was shown to be highly pathogenic to juvenile grouper (Fig. 6). Challenged fish had a cumulative mortality of $96 \% 10 \mathrm{~d}$ after injection, as compared with $13 \%$ mortality in the control fish. The mortality of the virus-challenged group rapidly increased after Day 3 post-infection. Hemorrhage and enlargement of spleen were obser- ved in virus-challenged fish, and virus was re-isolated from the challenged fish. No clinical signs of disease or virus were detected in control fish.

\section{DISCUSSION}

The family Iridoviridae comprises 4 recognised genera: Iridovirus, Chloriridovirus, Ranavirus (type virus, FV3) and Lymphocystivirus (type species, fish lymphocystis disease virus, LCDV) (Williams et al. 2000). Iridoviruses found in fish species have been classified into the genera of Ranavirus and Lymphocystivirus. Iridoviruses from genus Ranavirus cause systemic infection in many fish, while LCDV is associated with hyperplasia of connective tissue (Ahne et al. 1997). In this paper, we report the successful isolation of a pathogenic virus from diseased malabar and brown-spotted groupers, and the investigation of morphological, pathogenic, biochemical and molecular characteristics of the virus. The available data suggest that the virus most likely represents a novel Ranavirus species. This is the first report of biochemical and preliminary molecular characterisation of the grouper iridovirus isolated in Singapore. Thus, the virus was designed as Singapore grouper iridovirus (SGIV).

Most iridoviruses cause cytopathic effects in various cell cultures (Ahne et al. 1997). However, the SGD virus did not cause CPE in seabass or BF-2 cell lines, which support growth of most piscine ranaviruses (Chua et al. 1994). The grouper iridovirus of Taiwan (TGIV) can replicate and cause $\mathrm{CPE}$ in a grouper cell line (KRE), but virus infectivity was rapidly lost during serial passages (Chou et al. 1998). The lack of suitable cell lines limited the propagation, purification and further biochemical characterisation of SGIV. In our study, SGIV was successfully isolated using a new GP cell line. The virus infectivity is stable in GP cells, and can yield titers of $10^{6.0}$ $\mathrm{TCID}_{50} \mathrm{ml}^{-1}$. Thus, it is possible to obtain high quantities of purified virus. In addition, the virus grown in GP cells could cause rapid CPE and high titers in the cell lines of SF and FHM respectively, whereas slow CPE and low yields in EPC and BF-2 were observed, as compared with other fish iridoviruses (Eaton et al. 1991, Nakajima \& Sorimachi 1994, Piaskoski \& Plumb 1999).

The ultrastructure and size of SGIV are very similar to those piscine and amphibian iridoviruses belonging to genus Ranavirus (Hyatt et al. 2000). Intracellular virus nuclecapsids were found only in the cytoplasm of the infected cells. The mature virus particles were enveloped by budding through plasma membrane with a mean diameter of $200 \mathrm{~nm}$.

The physio-chemical properties of SGIV resemble those of other fish iridoviruses (Nakajima \& Sorimachi 1994, Chou et al. 1998, Tapiovaara et al. 1998, Piaskoski \& Plumb 1999). The virus infectivity was dra- 

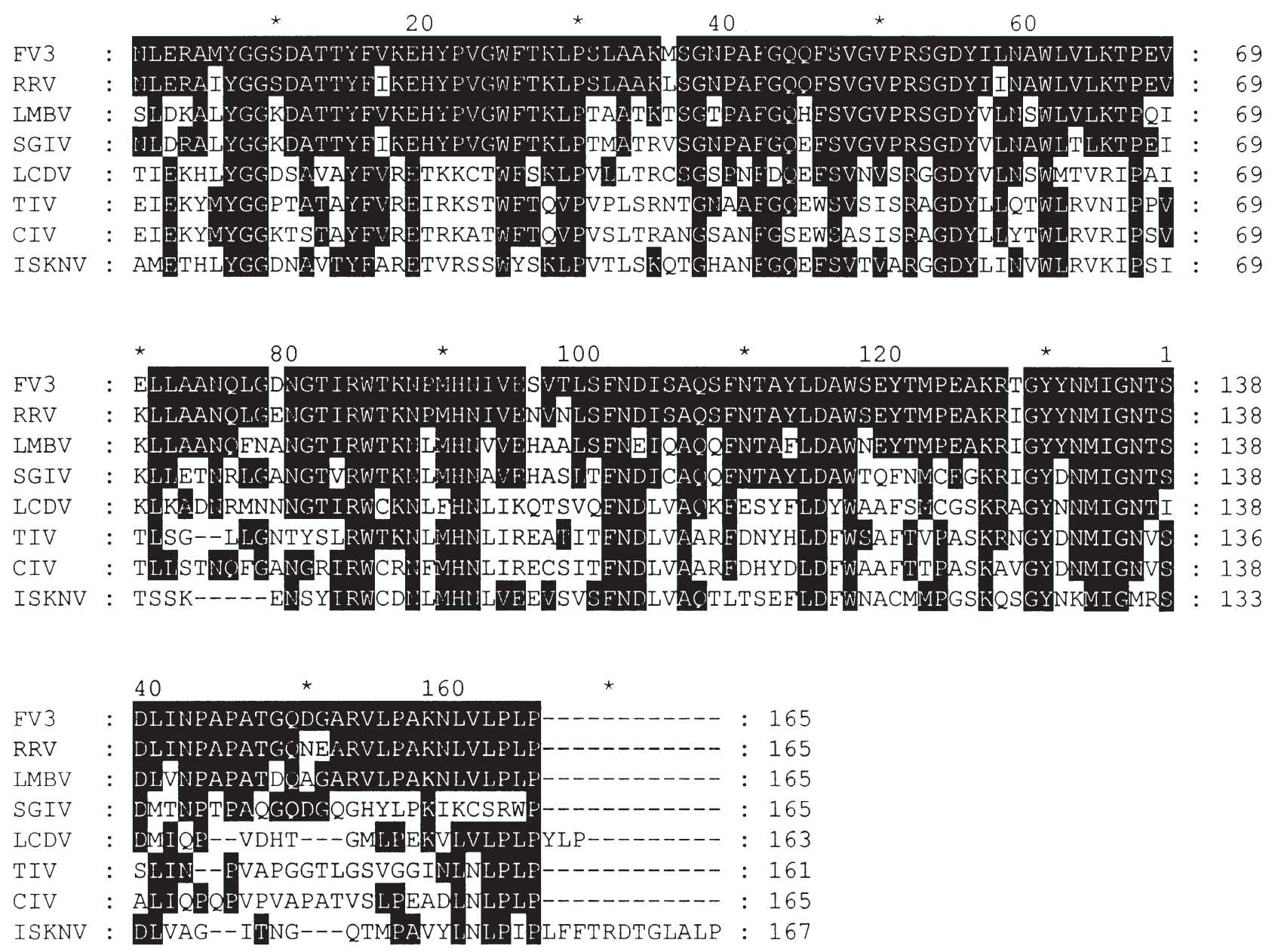

Fig. 4. Deduced amino acid sequences of part of the SGIV MCP and alignment of the N-terminus of the MCP of SGIV with representative iridoviruses of FV3, LMBV, LCDV, TIV and CIV. The multiple alignment was generated using Clustal X included in the GenDoc software package. Amino acid sequences that are identical to the FV3 sequence are indicated by shading. Amino acid 1 in this figure corresponds to amino acid 21 in the full-length sequence of FV3 MCP (Mao et al. 1996). Amino acid sequences encoded by the oligonucleotide primers are not included in the alignment

matically reduced after treatment with ether and virus replication was inhibited by IUDR indicating that the cytopathogenic agent is a lipid containing virus with a DNA genome.

The protein profiles of iridoviruses are similar and the highly conserved viral MCP serves as a valuable molecule in comparative studies. More than 20 similar polypeptides in the range of 8 to $121 \mathrm{kDa}$ were detected in FV3 or other vertebrate iridoviruses. All the viruses possessed a 48 to $49 \mathrm{kDa} \mathrm{MCP}$ (Mao et al. 1999, Hyatt et al. 2000). In the present study, it was possible to distinguish at least 20 protein bands by Coomassie Brilliant Blue staining in the SDS-PAGE of purified SGIV, the virus also possessed a MCP of $49 \mathrm{kDa}$. Since FV3 was not found in Singapore, we could not obtain enough FV3 for PAGE.

To confirm the morphological and biochemical studies and understand the phylogenetic relationship of
SGIV with FV3, the MCP gene was amplified and cloned. Primers were designed from highly conserved regions of FV3 MCP and have been used for amplifying the N-terminus of the MCP gene of several iridoviruses (Mao et al. 1997, 1999, Marschang et al. 1999). In comparison with the negative control (DNA from mockinfected GP cells) and positive control (FV3), a 500 bp PCR product was successfully obtained from DNA extracted from virus-infected cells. The PCR results suggest SGIV may belong to the genus Ranavirus. Further sequence analysis showed that the amplified MCP gene of SGIV is more closely related to FV3 (the type species of genus Ranavirus), RRV (a novel ranavirus isolated from tiger salamanders Ambystoma tigrinum diaboli, Bollinger et al. 1999) and LMBV (a ranavirus isolated from largemouth bass Micropterus salmoides) than to LCDV (the type species of genus Lymphocystivirus), ISKNV (isolated from mandarin fish Siniperca 


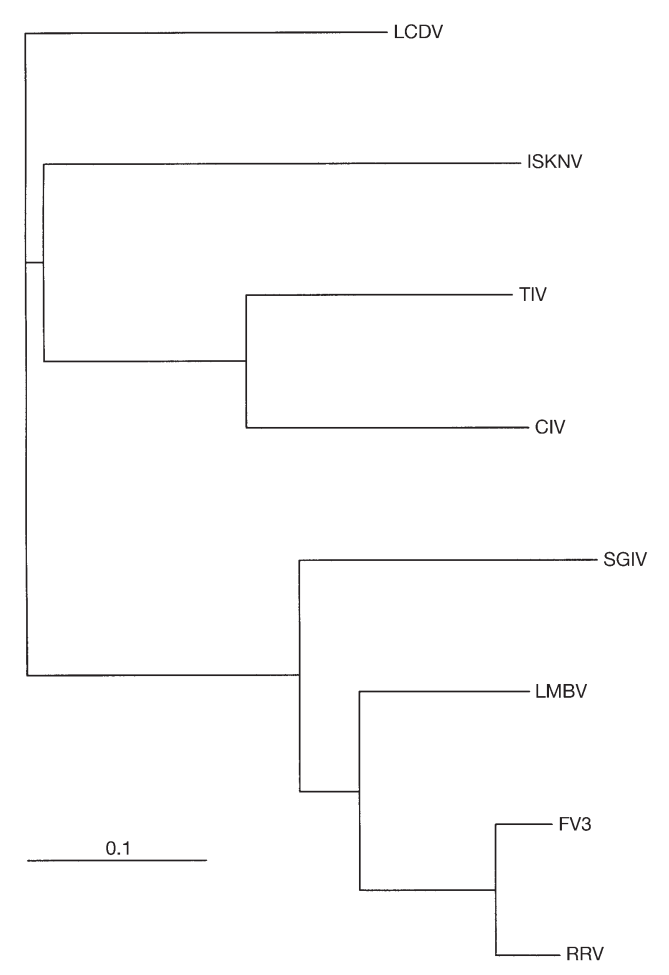

Fig. 5. Phylogenetic analysis showing the relationship of SGIV with representative iridoviruses. The phylogenetic tree was constructed using Clustal X included in the Treeview program based on the alignment shown in Fig. 4. Branch length is proportional to the numbers of amino acid substitutions indicated by the scale bar in the bottom left corner

chuatsi Basilewski, which may belong to a new genus of the Iridoviridae family; He et al. 2001), CIV or TIV. SGIV showed only low identity to FV3, RRV and LMBV $(69,69$ and $70 \%$ respectively). The phylogenetic analysis indicated that all of the examined ranaviruses were grouped separately from LCDV and ISKNV, and SGIV was distinct from FV3, RRV and LMBV. This work suggests that SGIV is a novel species of genus Ranavirus. The taxonomic designation is based on the suggestions of Ward (1993) that a common gene set, along with moderate sequence identity of 35 to $85 \%$ is important in defining members of a genus. Viruses with sequence identities within a given gene of less than $80 \%$ are considered members of different species rather than strains of the same species. Additional sequence studies of the complete nucleotide sequences of the virus MCP gene and whole viral genome are underway.

SGIV caused serious systemic diseases and resulted in more than $90 \%$ mortality in grouper either in fish farm or challenge experiments. The virus infection is characterized as hemorrhage and enlargement of the spleen of infected fish. Both sequence analysis and the clinical appearance of infected fish support the view that SGIV is a ranavirus, and not a member of the

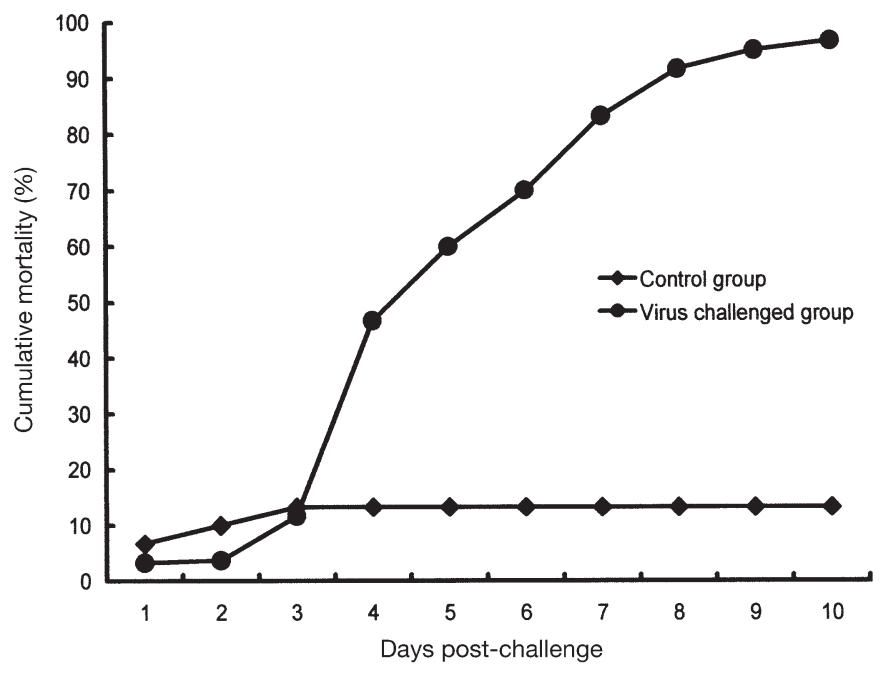

Fig. 6. Study of the virus pathogenicity to grouper Epinephelus tauvina. A $96 \%$ of cumulative mortality was obtained in grouper, E. tauvina (mean weight of $10 \mathrm{~g}$ ) experimentally challenged by intraperitoneal injection with the grouper virus $\left(10^{5} \mathrm{TCID}_{50} 0.1 \mathrm{ml}^{-1}\right.$ fish $\left.^{-1}\right)$ for $10 \mathrm{~d}$; this is in comparison with $13 \%$ mortality in the control fish injected with non-infected GP cell culture supernatant

genus Lymphocystivirus or a member of the recently proposed genus that includes red seabream iridovirus (RSIV) and ISKNV (He et al. 2001). Lymphocystiviruses infection is characterized by the appearance of wartlike lesions on the skin, whereas in RSIV and ISKNV infections are characterized by hypertrophy of infected cells. It is important to monitor SGIV spread and control the viral disease in mariculture in Singapore as well as other parts of SE Asia. Developments of diagnostic techniques and vaccines against the iridoviral disease are also being undertaken.

Acknowledgements. We gratefully acknowledge Ms G. L. Loy for her assistance with electron microscopy. This study is supported by A*STAR (Agency for Science, Technology and Research) of Singapore (Project Codes: C-347-001-002-001 MAP/QY/FD1 and R-347-000-027-305).

\section{LITERATURE CITED}

Ahne W, Schlotfeldt HJ, Ogawa M (1989) Fish viruses: isolation of an icosahedral cytoplasmic deoxyribovirus from sheatfish (Silurus glanis). J Vet Med B 36:333-336

Ahne W, Bremont M, Hedrick RP, Hyatt AD, Whittington RJ (1997) Iridoviruses associated with epizootic haematopoietic necrosis (EHN) in aquaculture. World J Microbiol Biotech 13:367-373

Bloch B, Larsen JL (1993) An iridovirus-like agent associated with systemic infection in cultured turbot Scophthalmus maximus fry in Denmark. Dis Aquat Org 15:235-240

Bollinger TK, Mao J, Schock D, Brigham RM, Chinchar VG (1999) Pathology, isolation, and preliminary molecular 
characterization of a novel iridovirus from tiger salamanders in Saskatchewan. J Wildl Dis 35:413-429

Chang SF, Ngoh GH, Kueh LFS, Qin QW, Chen CL, Lam TJ, Sin YM (2001) Development of a tropical marine fish cell line from Asian seabass (Lates calcarifer) for virus isolation. Aquaculture 192:133-145

Chew-Lim M, Ngoh GH, Ng MK, Lee JM, Chew P , Li J, Chan YC, Howe JLC (1994) Grouper cell line for propagating grouper viruses. Singapore J Primary Ind 22:113-116

Chong SY, Ngoh GH, Ng MK, Chu KT (1987) Growth of lymphocystis virus in a seabass, Lates calcarifer Bloch, cell line. Singapore Vet J 11:78-85

Chou H-Y, Hsu C-C, Peng T-Y (1998) Isolation and characterization of a pathogenic iridovirus from cultured grouper (Epinephelus sp.) in Taiwan. Fish Pathol 33:201-206

Chua FHC, Ng ML, Ng KL, Loo JJ, Wee JY (1994) Investigation of outbreaks of a novel disease, 'Sleepy Grouper Disease', affecting the brown-spotted grouper, Epinephelus tauvina Forskal. J Fish Dis 17:417-427

Eaton BT, Hyatt AD, Hengstberg S (1991) Epizootic haematopoietic necrosis virus: purification and classification. J Fish Dis 14:157-169

Fijan N, Sulimanovic M, Bearzotti M, Muzinic D, Zwillenberg LO, Chilmonczyk S, Vautherot JF, de Kinkelin P (1983) Some properties of the epithelioma papillosum cyprini (EPC) line from common carp Cyprinus carpio. Ann l'Inst Pasteur Virol 134:207-220

Gravell M, Malsberger RG (1965) A permanent cell line from the fathead minnow (Pimephales promelas). Ann NY Aca Sci 126:555-565

He JG, Deng M, Weng SP, Li Z, Zhou SY, Long QX, Wang XZ, Chan SM (2001) complete genome analysis of the mandarin fish infectious spleen and kidney necrosis iridovirus. Virology 291:126-139

Hyatt AD, Gould AR, Zupanovic Z, Cunningham AA, Hengstberger S, Whittington RJ, Kattenbelt J, Coupar BEH (2000) Comparative studies of piscine and amphibian iridoviruses. Arch Virol 145:301-331

Inouye K, Yamano K, Maeno Y, Nakajima K, Matsuoka M, Wada Y, Sorimachi M (1992) Iridovirus infection of cultured red sea bream, Pagrus major. Fish Pathol 27:19-27

Kasornchandra J, Khongpradit R (1995) Isolation and preliminary characterization of a pathogenic iridovirus-like agent in nursing grouper Epinephelus malabaricus. Asian Aquac Health News 4:5

Laemmli UK (1970) Cleavage of structural proteins during the assembly of the head of bacteriophage T4. Nature 227: $680-685$

Langdon JS, Humphrey JD, Williams LM, Hyatt AD, Westbury HA (1986) First virus isolation from Australian fish: an iridovirus-like pathogen from redfin perch, Perca fluviatilis L. J Fish Dis 9:262-268

Mao JH, Tham TN, Gentry GA, Aubertin AM, Chinchar VG (1996) Cloning, sequence analysis, and expression of the

Editorial responsibility: Jo-Ann Leong,

Kaneohe, Hawaii, USA major capsid protein of the iridovirus frog virus 3. Virology 216:431-436

Mao J, Hedrick RP, Chinchar VG (1997) Molecular characterization, sequence analysis, and taxonomic position of newly isolated fish iridoviruses. Virology 229:212-220

Mao J, Wang J, Chinchar GD, Chinchar VG (1999) Molecular characterization of a ranavirus isolated from largemouth bass Micropterus salmoides. Dis Aquat Org 37:107-114

Marschang RE, Becher P, Posthaus H, Wild P, Thiel H-J, Muller-Doblies U, Kaleta EF, Bacciarini LN (1999) Isolation and characterization of an iridovirus from Hermann's tortoises (Tsetudo hermanni). Arch Virol 144: 1909-1922

Nakajima K, Sorimachi M (1994) Biological and physicochemical properties of the iridovirus isolated from cultured red sea bream, Pagrus major. Fish Pathol 29:29-33

Page RDM (1996) TREEVIEW: an application to display phylogenetic trees on personal computers. Comput Appli Biosci 12:357-358

Piaskoski TO, Plumb JA (1999) Characterization of the largemouth bass virus in cell culture. J Aquat Anim Health 11: $45-51$

Plumb JA, Grizzle JM, Young HE, Noyes AD, Lamprecht S (1996) An iridovirus isolated from wild largemouth bass. J Aquat Anim Health 8:265-270

Pozet F, Morand M, Moussa A, Torhy C, de Kinkelin P (1992) Isolation and characterization of a pathogenic icosahedral deoxyribovirus from the catfish Ictalurus melas. Dis Aquat Org 14:35-42

Reed LJ, Muench H (1938) A simple method of estimating fifty percent endpoints. Am J Hyg 27:493-497

Steiner KA, Whittington RJ, Petersen RK, Hornitzky C, Garnett $H$ (1991) Purification of epizootic haematopoietic necrosis virus and its detection using ELISA. J Virol Methods 33:199-209

Tapiovaara H, Olesen NJ, Linden J, Rimaila-Parnanen E, von Bonsdorff CH (1998) Isolation of an iridovirus from pikeperch Stizostedion lucioperca. Dis Aquat Org 32:185-193

Thompson JD, Gibson TJ, Plewniak F, Jeanmougin F, Higgins DG (1997) The Clustal X windows interface: flexible strategies for multiple sequence alignment aided by quality analysis tools. Nucleic Acids Res 24:4876-4882

Ward CW (1993) Progress towards a higher taxonomy of viruses. Res Virol 144:419-453

Williams T, Chinchar D, Darai G, Hyatt A, Kalmakoff J, Seligy V (2000) Family iridoviridae. In: Virus taxonomy: Seventh Report of the International Committee on Taxonomy of Viruses. In: van Regenmortel MHV, Fauquet CM, Bishop DHL, Carstens EB, Estes MK, Maniloff J, Mayo MA, McGeoch DJ, Pringle CR, Wickner EB (eds). Academic Press, San Diego, CA, p 167-182

Wolf KM, Quimby M (1966) Lymphocystis virus: isolation and propagation in centrarchid fish cell lines. Science 151: 1004-1005

Submitted: July 24, 2002; Accepted: June 17, 2002 Proofs received from author(s): December 12, 2002 